\title{
Potential Use of an Essential Oil From the Flower of Swertia densifolia as a Repellent for Apis florea (Hymenoptera: Apidae)
}

\author{
Authors: D.G. Naik, H. Vaidya-Kannur, P.V. \\ Deshpande, C.N. Dandge, \& G.V.P Reddy
}

This is a pre-copyedited, author-produced PDF of an article accepted for publication in Annals of the Entomological Society of America following peer review. The version of record [Naik, D. G., H. Vaidya-Kannur, P.V. Deshpande, C. N. Dandge, and G.V.P. Reddy. 2015. Potential use of an essential oil from flower of Swertia densifolia as a repellent for Apis florea (Hymenoptera:

Apidae). Annals of the Entomological Society of America 108: 18-25.] is available online at:

http://dx.doi.org/10.1093/aesa/sau005.

Naik, D. G., H. Vaidya-Kannur, P.V. Deshpande, C. N. Dandge, and G.V.P. Reddy. 2015.

Potential use of an essential oil from flower of Swertia densifolia as a repellent for Apis florea (Hymenoptera: Apidae). Annals of the Entomological Society of America 108: 18-25. 


\title{
Potential Use of an Essential Oil From the Flower of Swertia densifolia as a Repellent for Apis florea (Hymenoptera: Apidae)
}

\author{
D.G. Naik, ${ }^{1,2}$ H. Vaidya-Kannur, ${ }^{1}$ P.V. Deshpande, ${ }^{1}$ C.N. Dandge, ${ }^{1}$ and G.V.P Reddy ${ }^{3}$ \\ 1 Chemistry Group, Agharkar Research Institute, G. G. Agarkar Road, Pune-411004, India. \\ 2 Corresponding author, e-mail: dgnpune@yahoo.co.in \\ 3 Montana State University \\ Western Triangle Agricultural Research Center, \\ 9546 Old Shelby Rd., P.O. Box 656, Conrad, MT 59425, USA.
}

\begin{abstract}
Formulations of compounds repellent to honey bees may be useful tools to keep bees away from areas recently treated with toxic insecticides. Here, we report the activity of a previously unknown honey bee repellent, an essential oil from the flower of Swertia densifolia (Gentianaceae), which has activity toward Indian honey bees Apis florea F. The essential oil was obtained by hydrodistillation and was subjected to a rotating table bioassay with foragers of the honey bee A. florea. Repellency was dose-dependent up to $12 \mathrm{mg} / \mathrm{ml}$ and remained constant thereafter. The chemical constitution of the essential oil was examined by gas chromatography-mass spectrometry analyses, which identified 19 constituent compounds. The major constituents ( $>10 \%$ of the oil) were linalool and octadecanoic acid. The constituents of intermediate concentration (5-10\%) were $\alpha$-terpeniol, nerol, $n$-octadecyl acetate, and spirostan-3-ol. Besides these, five minor constituents (1-5\%) and six of the eight trace components present $(<1 \%)$ have also been identified. The response of $A$. florea foragers to mixtures of the major and intermediate constituents was studied. Screening of formulations of linalool and $\alpha$-terpeniol showed repellent properties toward A. florea, behavior which has already been reported by us in earlier studies. The compound $n$-octadecyl acetate was found to be an attractant, while octadecanoic acid and spirostan3-ol were neither attractants nor repellents. Nerol, however, elicited dose-dependent effects involving both attraction and repellency. The effects of the constituents of this essential oil were not merely additive, possibly due to synergistic effects. These results establish the previously unknown chemical constitution and dose-dependent repellent nature of the essential oil isolated from flower of $S$. densifolia toward A. florea and may be used to improve bee management.
\end{abstract}

KEY WORDS Swertia densifolia, Apis florea, essential oil, GC-MS analysis, honey bee repellent

\section{Introduction}

Honey bees (Apis spp.) are one of the most important pollinator groups in nature, and are commonly exposed to insecticides used to control crop pests. Bee repellents are an important tool for keeping honey bees away from insecticide-treated areas. The earliest application of repellents to protect bees was the addition of carbolic acid to insecticide sprays to repel honey bees (Callbreth 1900). Since this initial study, many classes of synthetic compounds have been tested as bee repel-lents, including various carbonyl compounds, amines, alcohols, and aromatic compounds. The search for nat-urally occurring honey bee repellents has focused on the repellent activity of essential oils from plants (Suku-mar et al. 1991, Mishra 1997). A honey bee repellent composed of tea tree oil, benzaldehyde, and alcohol has been patented (Sackin and Fishman 1998), while the repellent effects of several natural substances in-cluding extracts of Nicotiana tabacum (tobacco), Ruta graveolens (rue), Allium sativum (garlic), Carum pteroselinum (parsley), and Agave Americana (century) plants (Nicodemo and Nogueiracouto 2004) have demonstrated the efficacy of plant extracts as bee repellents. A model has been developed to score the repellency of compounds to honey bees (Ridout et al. 2006), and recent reviews substantiate the effectiveness of essential oils and botanical extracts as repellents suitable for use in modern agriculture (Nerio et al. 2010, Regnault-Roger et al. 2012, Khater 2012). Woodsetal. (2014) have even patented substituted carbocyclic and heterocyclic organic compounds as bee repellents. Most previous reports found activity of intact essential oils to be superior to that of their individual constituents, indicating a synergistic effect among components (Nerio et al. 2010).

In our efforts to develop attractants for honey bees, pheromone-based "lures" were developed first (Naik et al. 1989). However, their limitations were also evident.Itwasseenthatoptimumactivityoflureswas

observed only over a small range of concentrations of

attractant formulations. Formulations of higher or lower concentrations were less attractive. Development of plant-based attractant formulations was thought to be a possible alternative (Naik et al. 2003). It is frequently observed by beekeepers in western Maharashtra (India) that Swertia densifolia Griseb. 
(Gentianaceae), popularly known as "Chirayata," (Fig. 1) is often visited by foragers of honey bees in open fields. We, therefore, screened extracts of $S$. densifolia on honey bees. Initially, a dose-dependent attractant and repellent activity of a leaf extract of this plant toward A. florea (Hymenoptera: Apidae) was demonstrated (Naik et al. 2005). This was followed by the isolation of the essential oil from leaves and demonstration of its repellency to A. florea (Naik et al. 2008). Study of the biological properties of extracts of the leaf left after removal of the essential oil demonstrated dose-dependent attractant properties at lower concentrations and repellent properties at higher concentrations, a response pattern similar to that shown by insects to pheromones (Naik et al. 2010a). While this previous work demonstrated the value of extracts from the leaves of S. densifolia, the chemical constitution and biological properties of the essential oils from the flowers of $S$. densifolia have not previously been examined and are reported here.

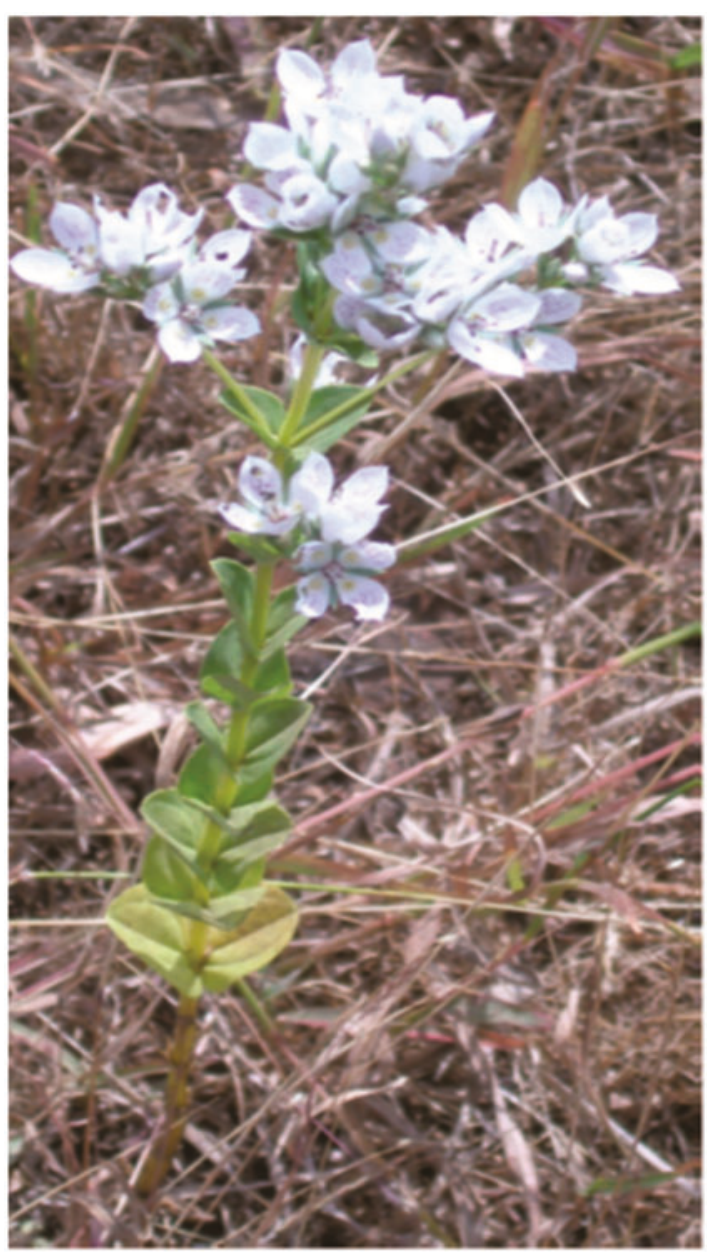

Fig. 1. S. densifolia plant showing flowers.

\section{Materials and Methods}

Collection of Plant Material. Complete plant of $S$. densifolia $(5 \mathrm{~kg})$ were collected from each of the three locations $(\approx 1.75 \mathrm{~kg}$ from each location) in the Mahabaleshwar region of western Maharashtra, India: 1) near "Table Land," Wai ( $17^{\circ} 57^{\prime}$ N, 73 53' E; $1371 \mathrm{~m}$ above msl); 2) near "Venna Lake," Mahabaleshwar (17 $56^{\prime}$ $\mathrm{N}, 73^{\circ} 39^{\prime} \mathrm{E}$; $1439 \mathrm{~m}$ above $\mathrm{msl}$ ); and 3) near "Arthur Seat," Mahabaleshwar $\left(17^{\circ} 58^{\prime} \mathrm{N}, 73^{\circ} 38^{\prime} \mathrm{E} ; 1340 \mathrm{~m}\right.$ above msl). Plant specimens were taxonomically identified by the Botany Group of the Agharkar Research Institute (Voucher No. WP- 115). Flowers (750 g) from each location were subdivided into three equal parts, and the essential oil from each lot was extracted.

Isolation of Essential Oil by Hydrodistillation. Flowers $(250 \mathrm{~g})$ from each lot (three lots per site) were subjected to hydrodistillation for $4 \mathrm{~h}$ using a Clevenger apparatus, and the average yield of essential oil per $250 \mathrm{~g}$ of flowers was determined. The essential oil from each lot was carefully collected using a long-tipped dropper to avoid possible contamination in solvent extraction.

Analyses of the Essential Oil. Primary examination of the essential oil was carried out by thin-layer chromatography. Next, the chemical constituents of the essential oil were identified by gas chromatographymass spectrometry (GC-MS) analyses. The essential oil $(5 \mu \mathrm{l})$ was dissolved in dry acetone $(1 \mathrm{ml})$, and a portion of the solution $(2 \mu \mathrm{l})$ was injected into a Shimadzu QP5000 GC-MS spectrometer fitted with a DB-5 capillary column $(30 \mathrm{~m} \times 0.32 \mathrm{~mm}$ i.d., film thickness $0.25 \mu \mathrm{m})$. NIST and Wiley libraries were installed for reference. Injector was used in split mode, with a 28: 1 split ratio. The column temperature was programed for optimal separation of components in three stages: 1) $70^{\circ} \mathrm{C}$ $(5 \mathrm{~min}), 2)$ increasing from $70^{\circ}$ to $200^{\circ} \mathrm{C}$ at $10^{\circ} \mathrm{C} / \mathrm{min}$, and 3) $200^{\circ} \mathrm{C}(25 \mathrm{~min})$; injector temperature, $200^{\circ} \mathrm{C}$; interphase temperature, $230^{\circ} \mathrm{C}$; carrier gas, $\mathrm{He}(10 \mathrm{ml}$ min); ionization energy, $70 \mathrm{eV}$; scan time, $0.5 \mathrm{~s}$; mass range $45-450 \mathrm{~m} / \mathrm{z}$; solvent cut, $4 \mathrm{~min}$; start time, $5 \mathrm{~min}$. Identification of the compounds was done by studying their mass spectral fragmentation patterns and using the NIST and Wiley library searches. These assignments were then confirmed by studying their reported Kovats retention indices. Further confirmation of assignments was done by Co-GC analyses with known standards of available authentic compounds. Quantification of each constituent was done by following the standard procedure reported in our earlier paper (Naik et al. 2011).

Procedure for the Bioassay. A natural colony of Indian honey bees A. florea nested in open space on the campus of Agharkar Research Institute was used for bioassays. Bioassays of each of the test formulation were carried out using a rotating table bioassay (Naik et al. 2013), in which a table with a rotating circular wooden top $(60 \mathrm{~cm}$ in diameter) mounted on an electric motor was fitted with a removable glass top of the same diameter. Throughout the experiment, the table top was $25 \mathrm{~cm}$ above the ground and was rotated at a constant velocity of one rotation every three minutes. A 
quantity of $50 \mu \mathrm{l}$ of the test formulation was placed on each of eight predried cylindrical blocks of plaster of Paris $(1 \mathrm{~cm}$ in diameter and $1 \mathrm{~cm}$ in height). These blocks were arranged symmetrically in a petri dish $(8 \mathrm{~cm}$ in diameter). Another petri dish with eight similar blocks loaded with $50 \mu \mathrm{l}$ of liquid paraffin was prepared as a control. Before beginning the actual experiment, the worker bees of A. florea were trained to feed on sugar syrup placed in a dish on the rotating table. After $\approx 100$ bees had been trained, the glass top of the table was replaced with another identical glass top on which a petri dish with the test formulation and another petri dish with the control were placed opposite $(40 \mathrm{~cm}$ apart) one another. Each petri dish was covered with clean, dry wire gauze (15- by $15-\mathrm{cm}$ piece). The number of bees visiting each dish during a 10-min period was recorded. This time frame was selected based on preliminary observations that the rate of visits by honey bees remained unaffected for $10 \mathrm{~min}$ even when the feeding dish was removed. The wire gauze on the dishes was changed once any wire gauze had been touched by a bee, to avoid the effect of any pheromone it might have deposited. Honey bee response was assessed for seven formulations of increasing concentration, prepared by mixing a weighed quantity of essential oil (2-14 mg) with liquid paraffin (1 ml). A set of seven observations was recorded for each concentration. The averages and the standard deviations were calculated. The mean difference $(\Delta \mathrm{R})$ between the average number of bees visiting the control and that visiting each concentration was estimated as a measure of repellency of the test formulation. If the number of bees visiting the dish containing the test formulation was more than the number visiting the control, its attractiveness $(\Delta \mathrm{A})$ was determined as the difference between the average number of bees visiting the test formulation and that visiting the control.

Bioassays of one of the major compound linalool and one of the intermediate compound $\alpha$-terpeniol was already carried out by us (Naik et al. 2008). Bioassays of the remaining major compound octadecanoic acid and the intermediate compounds nerol, $n$-octadecyl acetate, and spirostan-3-ol toward A. florea were carried out in this study.
Statistical Analyses. Statistical analyses were carried out using Mann-Whitney test and Kruskal-Wallis test to determine the significance of observations (SPSS version 11.0, SPSS Inc, Chicago, IL).

\section{Results}

Isolation of Essential Oil From Flower. In each of the nine hydrodistillations of $S$. densifolia flowers $(250 \mathrm{~g})$, the essential oil was obtained as a colorless fragrant liquid with an average yield of $59 \mathrm{mg}(0.024 \%$, wt:wt) per sample.

Chemical Composition of the Essential Oil. Examination of the essential oil by thin-layer chromatography using $n$-hexane: ethyl acetate (90:10) showed five distinct bands $\left(R_{f}\right.$ values $0.65,0.59,0.44,0.33$, and $0.08)$.

Gas chromatograms from GC-MS analyses of all nine samples of essential oil from S. densifolia were identical. A representative gas chromatogram obtained after GCMS analysis (Fig. 2) indicated the presence of 19 compounds (Table 1), of which two were major components (>10\%, wt:wt), four were intermediate (5-10\%, wt:wt), five were minor $(1-5 \%$, wt:wt), and eight were trace components $(<1 \%$, wt:wt). The method used for identification is also indicated in Table 1. The structures of these compounds are shown in Fig. 3.

Repellency of the Essential Oil Toward A. flora. We found that number of honey bees visiting the test formulations of the intact essential oil was always significantly lower for all nine samples than the number visiting the control (Mann-Whitney test, $P<$ 0.01; Kruskal-Wallis, $\left.\chi^{2}=62.59, P=0.0001\right)$, indicating the repellent nature of the essential oil (Table 2). Repellency varied by concentration (Fig. 4).

Bee Behavior Toward the Major and Intermediate Components of the Essential Oil. Bee behavior toward octadecanoic acid and spirostan3-ol was neutral relative to controls, as the number of bees visiting the test formulations did not differ from controls ( $11 \pm 2$ vs $11 \pm 2$ bees for octadecanoic acid; Mann-Whitney test, $P=0.42 ; 11 \pm 2$ vs $10 \pm 1$ bees for spirostan-3-ol; Mann-Whitney test, $P=0.37$; KruskalWallis, for both the compounds, $\chi^{2}=3.33, P=0.336$ ).

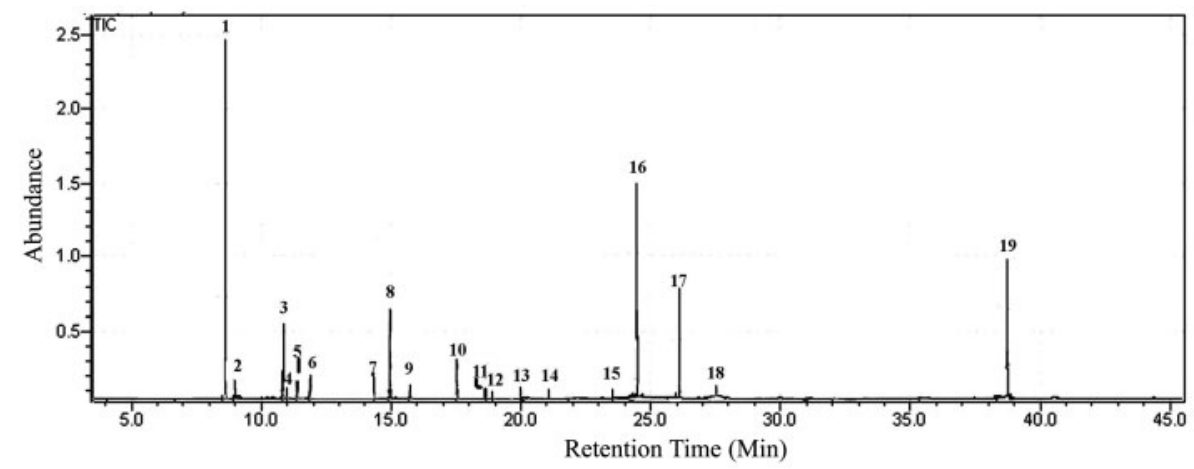

Fig. 2. Gas chromatogram of S. densifolia flower essential oil. 
Table 1. GC-MS analysis of essential oil from the flower of S. densifolia

\begin{tabular}{lcclcl}
\hline \hline Sr. no. & Retention time (RT; min) & Kovats index $(\mathrm{RI})^{a}$ & Name & Concn $(\%, w t: w t)$ & Methods of identification \\
\hline 1 & 8.6 & 1098 & Linalool & 31.7 & MS, RI, Co-GC \\
2 & 9.0 & - & Ho-trienol & 2.17 & MS \\
3 & 10.9 & 1188 & $\alpha$-Terpineol & 8.58 & MS, RI, Co-GC \\
4 & 11.0 & 1195 & Ethyl octanoate & MS, RI, Co-GC \\
5 & 11.4 & 1199 & Ethyl $(Z)-2$-octenoate & 0.58 & MS, RI \\
6 & 11.9 & 1227 & Nerol & 6.62 & MS, RI, Co-GC \\
7 & 14.3 & 1249 & Geraniol & 2.67 & MS, RI, Co-GC \\
8 & 15.0 & - & 4-Oxodecanal & 2.48 & MS \\
9 & 15.7 & 1464 & (E)-3-Dodecen-1-ol & 0.40 & MS, RI \\
10 & 17.6 & 1511 & (Z,E)-5,7-Dodecadien-1-ol & 4.17 & MS, RI \\
11 & 18.7 & - & Tetradecanoic acid & 0.31 & MS, Co-GC \\
12 & 19.0 & 1803 & (E)-5-Hexadecenal & 0.56 & MS, RI \\
13 & 20.1 & 1863 & Z)-9-Hexadecen-1-ol & 0.29 & MS, RI \\
14 & 21.9 & - & Heptadecanal & 0.37 & MS, Co-GC \\
15 & 23.6 & - & Unidentified & 0.33 & MS \\
16 & 24.5 & 2124 & Octadecanoic acid & 16.64 & MS, RI, Co-GC \\
17 & 26.0 & 2210 & $n$-Octadecyl acetate & 9.53 & MS, RI, Co-GC \\
18 & 27.7 & - & Unidentified & 0.49 & MS \\
19 & 38.8 & - & Spirostan-3-ol & 9.68 & MS, Co-GC \\
\hline
\end{tabular}

${ }^{a}$ Kovats indices reported in the literature. Classes identified: Alcohol (1-3, 6, 7, 9, 10, 13, 19; 61.45\%), Ester (4, 5, 17; 11.42\%), Aldehyde $(8,12,14 ; 7.47 \%)$, Acid $(11,16 ; 16.78 \%)$.<smiles>C=CC(C)(O)CCC=C(C)C</smiles><smiles>C=C[C@](C)(O)C/C=C\C(=C)C</smiles><smiles>CC1=CCC(C(C)(C)O)CC1</smiles><smiles>CCCCCCCC(=O)OCC</smiles>

Ethyl octanoate Ethyl (Z)-2-octenoate

\section{Linalool Ho-trienol $\alpha$-Terpeniol}<smiles>CC(C)=CCCC(C)=CCO</smiles><smiles>CC(C)=CCCC(C)=CCO</smiles><smiles>CCCCCCC(=O)CCC=O</smiles><smiles>CCCCCCCC/C=C/CCO</smiles>

\section{Nerol}

Geraniol

4-Oxodecanal

(E)-3-Dodecen-1-ol<smiles>CCCCC=CC=CCCCCO</smiles><smiles>CCCCCCCCCCCCCC(=O)O</smiles><smiles>CCCCCCCCCC/C=C/CCCC=O</smiles>

(Z, E)-5,7-Dodecadien-1-ol

Tetradecanoic acid

(E)-5-Hexadecanal

HO $\mathrm{CH}_{3}$<smiles>CCCCCCCCCCCCCCCCCCCC=O</smiles><smiles>NCCCCCCCCCCCCCCCCCCO</smiles>

(Z)-9-Hexadecen-1-ol Heptadecanal Octadecanoic acid

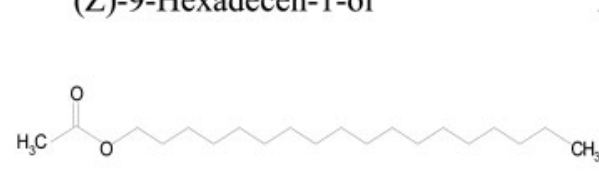

Octadecyl acetate

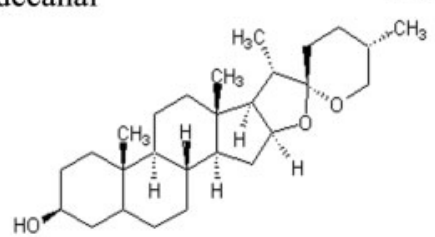

Spirostan-3-ol

Fig. 3. Structures of the compounds identified from S. densifolia flower essential oil. 
Bioassays of formulations of $n$-octadecyl acetate showed that this compound was significantly attractive to bees, with the level of attraction increasing up to a concentration of $100 \mathrm{mg} / \mathrm{ml}$ (Mann-Whitney test, $P<$ 0.01; Kruskal-Wallis test, $\left.\chi^{2}=54.39, P=0.0092\right)$. Further increase in concentration did not further increase attractiveness (Table 3; Fig. 5).

For the component nerol, low concentrations of 20 and $40 \mathrm{mg} / \mathrm{ml}$ were significantly attractive to A. florea foragers, and this attractiveness increased with increasing concentration up to $80 \mathrm{mg} / \mathrm{ml}$ (Mann-Whitney test, $P<0.01$; Kruskal-Wallis, $\left.\chi^{2}=52.41, P=0.0098\right)$. Further increase in concentration then reduced its level of attraction, with concentrations above $170 \mathrm{mg} / \mathrm{ml}$ being repellent (Table 4; Fig. 6).

Table 2. Average number of honey bees A. florea visiting test formulations of essential oil from the flower of $\mathrm{S}$. densifolia and that visiting the control at different concentrations

\begin{tabular}{lccc}
\hline $\begin{array}{l}\text { Concn } \\
(\mathrm{mg} / \mathrm{ml})^{a}\end{array}$ & $\begin{array}{l}\text { Avg no. of } \\
\text { bees visiting } \\
\text { control }^{b}\end{array}$ & $\begin{array}{l}\text { Avg no. of } \\
\text { bees visiting } \\
\text { test formulations }\end{array}$ & $\begin{array}{l}\text { Mean } \\
\text { difference } \Delta \mathrm{R} \\
\text { i.e. }\left({ }^{b}-{ }^{c} \pm \mathrm{SD}\right)\end{array}$ \\
\hline 2 & 18 & 14.5 & $3.5 \pm 1.17$ \\
4 & 20.1 & 12.7 & $7.4 \pm 0.96$ \\
6 & 22.4 & 11.9 & $10.5 \pm 0.84$ \\
8 & 24.3 & 11.2 & $13.1 \pm 1.52$ \\
10 & 23.2 & 7.5 & $15.8 \pm 1.47$ \\
12 & 25 & 5.7 & $17.2 \pm 1.75$ \\
14 & 22.7 & & $17 \pm 0.94$ \\
\hline \multicolumn{2}{c}{${ }^{a}$ Essential-oil concentration in mg/ ml of liquid paraffin. } \\
\multicolumn{3}{c}{ Average number of bees visiting control counted during a period } \\
of 10 min $(n=7)$. \\
${ }^{c}$ Average number of bees visiting the test formulation counted dur- \\
ing a period of 10 min $(n=7)$.
\end{tabular}

\section{Discussion}

Although flowers are known to attract honey bees for pollination, the observed repellency of the flower essential oil is intriguing. However, this is in agreement with the repellent activity observed for other essential oils. Essential oils from leaves of $S$. densifolia (Naik et al. 2008), fruits of Terminalia chebula (Naik et al. 2010b), and Indian propolis (Naik et al. 2013) have previously been reported as repellent to honey bees. In a continuation of this line of research, here we report the isolation of components of the essential oil of flowers of $S$. densifolia and characterization of their repellent properties. Repellency observed is comparable with that observed for a standard honey bee repellent 2-heptanone (Naik et al. 2002). Alcohols form the major class of compounds in this essential oil $(61.5 \%$, wt:wt). Acids (16.8\%,wt:wt) and esters (11.4\%,wt:wt) were present in moderate amounts, while the aldehydes $(7.7 \%$, wt:wt) were present at lower concentrations. Linalool was found to be a major constituent (>10\%, wt:wt) in the leaf essential oil of S. densifolia which showed repellent properties toward $A$. florea (Naik et al. 2008). Its presence as a major chemical constituent in the flower essential oil of S. densifolia, showing repellent properties toward A. florea, is in agreement with our earlier observations. Similarly, $\alpha$-terpeniol showed repellent properties in both leaf and flower essential oils of $S$. densifolia.

The repellent nature of the essential oil investigated in this study corresponds well with the repellent olfactory response of honey bees to various essential oils reported in previous studies (Gupta 1987).

The response of honey bees toward the individual components of the essential oil revealed a complex relationship between the activity of essential oil and the

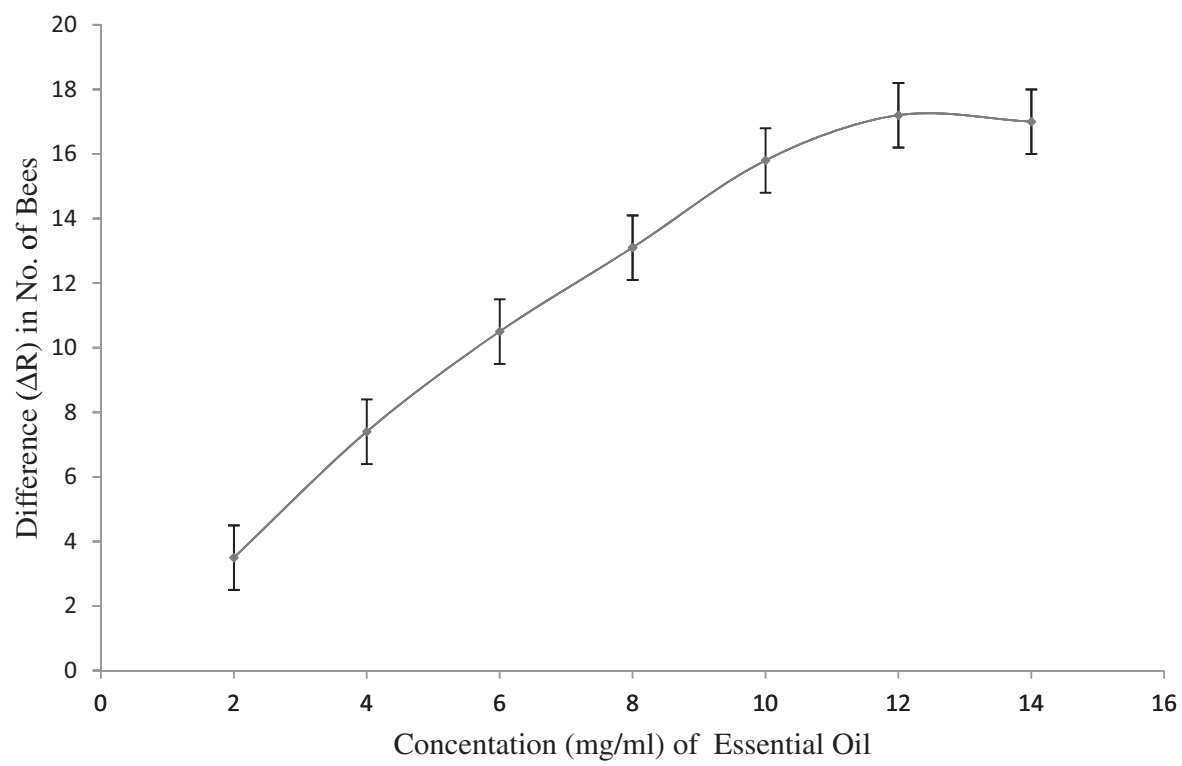

Fig. 4. Difference $(\Delta \mathrm{R})$ between the average number of honey bees visiting the dish containing liquid paraffin control and that visiting the dish containing the test formulation of $S$. densifolia flower essential oil versus concentration $(\mathrm{mg} / \mathrm{ml}) \mathrm{of}$ the test formulations. Standard deviation is shown at each point; $\chi^{2}=62.59, P=0.0001$, Kruskal-Wallis test. 
individual constituents. Screening of formulations of individual constituents suggested a synergistic behavior. The major component linalool and the intermediate component $\alpha$-terpineol have already been shown to be repellent toward A. florea (Naik et al. 2008). Combined, these compounds comprise $40.7 \%$ of the essential oil. Meanwhile, the bioassay of nerol showed it to have dose-dependent attractant or repellent properties. Screening of another major constituent, n-octadecyl acetate, found its attractant properties to increase with increasing concentration and then remain constant. Nerol and $n$-octadecyl acetate, both showed dosedependent attractant properties, and comprised $16.2 \%$ of the essential oil. The other two compounds with intermediate concentrations, octadecanoic acid and spirostan-3-ol, accounted for $26.3 \%$ of the essential oil and were inert toward $A$. florea. Considering their variation, it is evident that the properties of these individual constituents are not merely additive. This could be

Table 3. Average number of honey bees A. florea visiting test formulations of $n$-octadecyl acetate and that visiting the control at different concentrations

\begin{tabular}{lccc}
\hline $\begin{array}{l}\text { Concn } \\
(\mathrm{mg} / \mathrm{ml})^{a}\end{array}$ & $\begin{array}{l}\text { Avg no. of } \\
\text { bees visiting } \\
\text { control }^{b}\end{array}$ & $\begin{array}{l}\text { Avg no. of } \\
\text { bees visiting } \\
\text { test formulations }\end{array}$ & $\begin{array}{l}\text { Mean } \\
\text { difference } \Delta \mathrm{R} \\
\text { i.e. }\left({ }^{c}-{ }^{b} \pm \mathrm{SD}\right)\end{array}$ \\
\hline 20 & 18 & 19.6 & $1.6 \pm 0.94$ \\
40 & 22 & 25.2 & $3.2 \pm 1.01$ \\
60 & 20.6 & 26 & $5.4 \pm 1.21$ \\
80 & 19.2 & 26 & $6.8 \pm 0.84$ \\
100 & 21 & 31 & $8.0 \pm 1.42$ \\
120 & 23 & $29 \pm 1.14$ \\
\hline${ }^{a} n$-Octadecyl acetate concentration in mg/ ml of liquid paraffin. \\
${ }^{b}$ Average number of bees visiting control counted during a period \\
of 10 min $(n=7)$. \\
${ }^{c}$ Average number of bees visiting the test formulation counted dur- \\
ing a period of 10 min $(n=6)$.
\end{tabular}

due to the synergistic effects of other chemical constituents present in the essential oil. Many studies have reported synergism in the constituents of essential oils, and it is frequently noted that the complex essential oil components is considerably more efficacious than the pure compounds derived from them (e.g., oil of anise, rosemary oil, and various citrus oils; Don-Pedro 1996, Ho et al. 1997, Hori 1998). When wood preservative solutions of eucalyptus essential oil were studied, a synergistic effect from minor constituents was found (Khater 2012). Similarly, the synergistic effects of constituents of essential oils used in vector control have been demonstrated (Koul et al. 2008), and a recent study reported a synergistic effect of compounds of essential oils from Suregada zanzibariensis in repelling

Table 4. Average number of honey bees A. florea visiting test formulations of nerol and that visiting the control at different concentrations

\begin{tabular}{lccr}
\hline $\begin{array}{l}\text { Concn } \\
(\mathrm{mg} / \mathrm{ml})^{a}\end{array}$ & $\begin{array}{l}\text { Avg no. of } \\
\text { bees visiting } \\
\text { control }^{b}\end{array}$ & $\begin{array}{l}\text { Avg no. of } \\
\text { bees visiting } \\
\text { test formulations }\end{array}$ & $\begin{array}{l}\text { Mean } \\
\text { difference } \Delta \mathrm{R} \\
\text { i.e. }\left({ }^{c}-{ }^{b} \pm \mathrm{SD}\right)\end{array}$ \\
\hline 20 & 14.5 & 18 & $3.5 \pm 1.14$ \\
40 & 20.6 & 28.0 & $7.4 \pm 0.78$ \\
60 & 22.4 & 32.9 & $10.5 \pm 1.28$ \\
80 & 14.3 & 27.4 & $13.1 \pm 1.64$ \\
100 & 12.0 & 23.5 & $11.5 \pm 2.21$ \\
120 & 7.8 & 15 & $8.2 \pm 1.82$ \\
140 & 11.7 & 19.0 & $-2.1 \pm 0.92$ \\
160 & 17.4 & 22.9 & $-5.3 \pm 1.21$ \\
180 & 25.0 & 18.7 & \\
200 & 24.0 & & \\
\hline \multicolumn{2}{c}{ Nerol concentration in mg/ ml of liquid paraffin. } \\
${ }^{b}$ Average number of bees visiting control counted during a period \\
of 10 min $(n=7)$. \\
${ }^{c}$ Average number of bees visiting the test formulation counted dur- \\
ing a period of 10 min $(n=7)$.
\end{tabular}

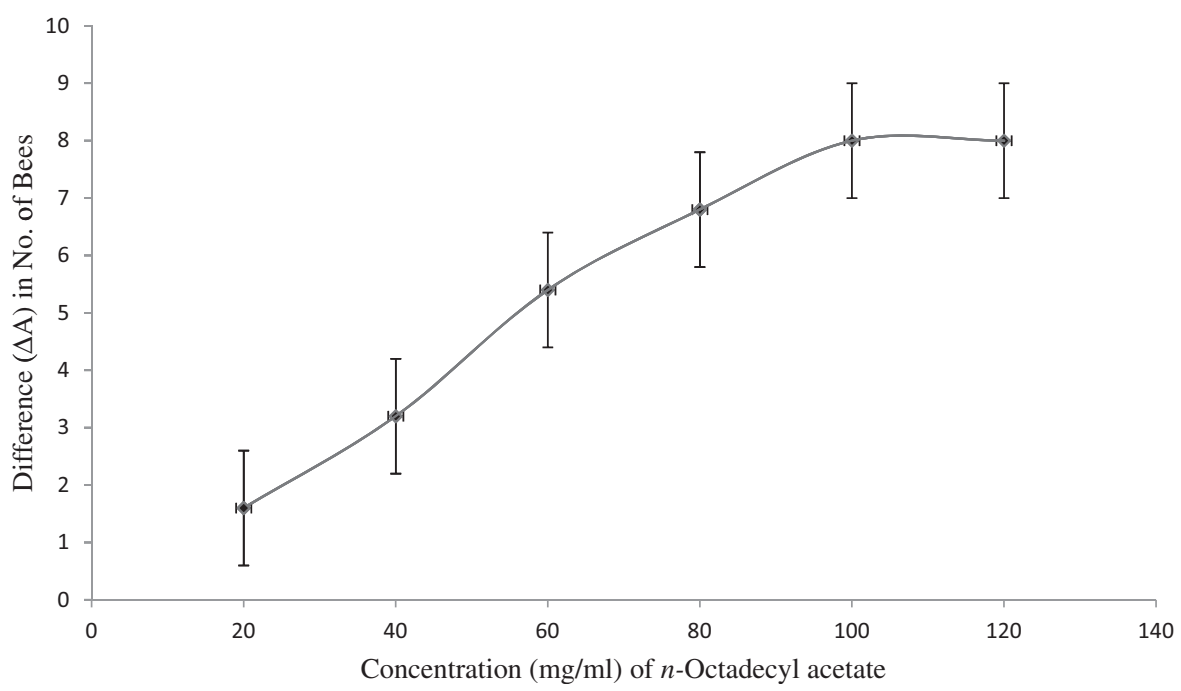

Fig. 5. Difference $(\Delta \mathrm{A})$ between the average number of honey bees visiting the dish containing the test formulation of $n$-octadecyl acetate and that visiting liquid paraffin control versus concentration $(\mathrm{mg} / \mathrm{ml})$ of the test formulations. Standard deviation is shown at each point; $\chi^{2}=54.39, P=0.0092$, Kruskal-Wallis test. 


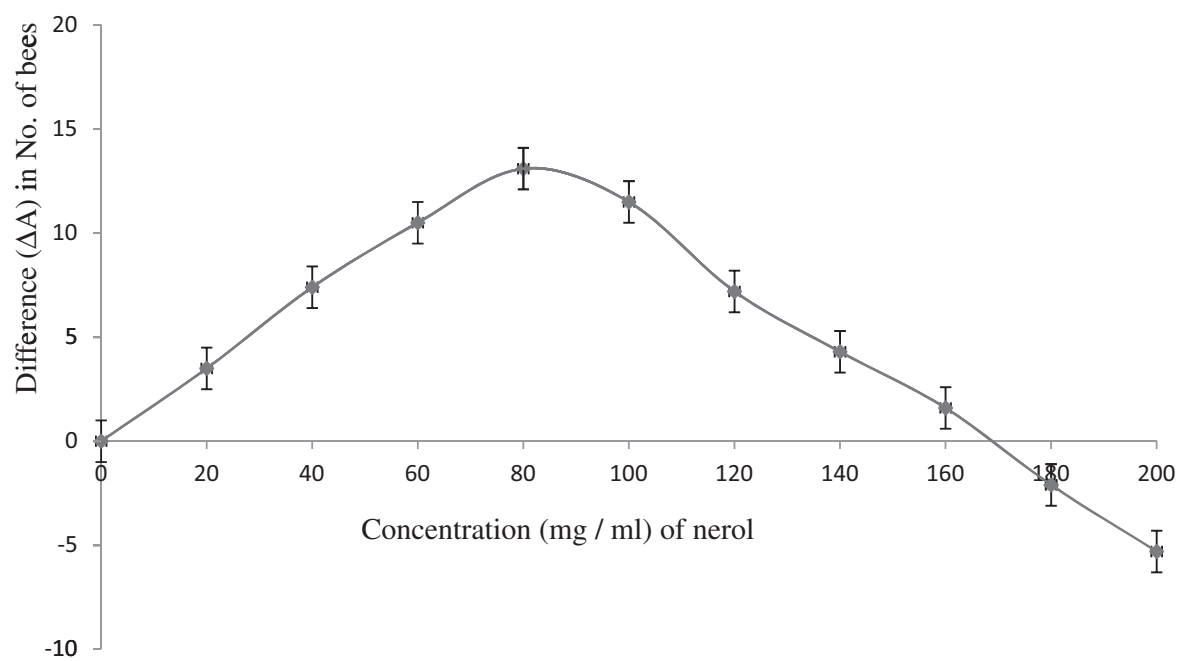

Fig. 6. Difference $(\Delta \mathrm{A})$ between the average number of honey bees visiting the dish containing the test formulation of nerol and that visiting liquid paraffin control versus concentration $(\mathrm{mg} / \mathrm{ml})$ of the test formulations. Standard deviation is shown at each point; $\chi^{2}=52.41, P=0.0098$, Kruskal-Wallis test.

female adult mosquitoes (Innocent et al. 2010). Another study of odorant receptor modulation in insect repellents also found a synergistic effect among the constituents of repellent formulation (Bohbot and Dickens 2012).

This study establishes the previously unknown chemical constitution of the essential oil isolated from the flower of $S$. densifolia and demonstrates the dosedependent repellent nature of the essential oil toward A. florea. Determining the repellency of such essential oils is important for keeping bee populations away from chemical insecticides used in crop fields. This essential oil can be isolated by individual beekeepers or by an industrial laboratory for practical applications. The essential oils of mint, thyme, rosemary, and lemon grass have been classified as GRAS (generally regarded as safe) in the United States and have been placed on a list of FIFRA Section 25(b) exempting them from the registration process needed for chemical applications (Regnault-Roger et al. 2012). If GRAS certification can be obtained for the essential oil components identified in this study, farmers could replace synthetic bee repellents with more environmentally friendly formulations of essential oils.

\section{Acknowledgments}

We thank Dr. Shashi Chiplonkar of Jahangir Hospital, Pune, India, for statistical analyses.

\section{References Cited}

Bohbot, J. D., and J. C. Dickens. 2012. Odorant receptor modulation: ternary paradigm for mode of action of insect repellents. Neuropharmacol. 62: 2086-2095.

Callbreth, J. S. 1900. The use of carbolic acid during spraying time. Gleaning Bee Cult. 28: 84.
Don-Pedro, K. N. 1996. Investigation of single and joint fumigant insecticidal action citrus peel oil components. Pestic. Sci. 46: 79-84.

Gupta, M. 1987. Olfactory response of Apis florea F. to some essential oils. J. Apic. Res. 26: 3-10.

Ho, S. H., Y. Ma, and Y. Huang. 1997. Anethole, a potential insecticide from Ilicium verum Hook F., against two stored product insects. Int. Pest Control 39: 50-51.

Hori, M. 1998. Repellency of rosemary oil against Myzus persicae in a laboratory and in a screenhouse. J. Chem. Ecol. 24: $1425-1432$.

Innocent, E., C. C. Joseph, N. K. Gikonyo, M.H.H. Nkunya, A. Hassanali. 2010. Constituents of the essential oil of Suregada zanzibariensis leaves are repellent to the mosquito, Anopheles gambiae s. s. J. Insect Sci. 10: 1-8.

Khater, H. F. 2012. Prospects of botanical biopesticides in insect pest management. Pharmacologia 3: 641-656.

Koul, O., S. Walia, G. S. Dhaliwal. 2008. Essential oils as green pesticides: potential and contraints. Biopest. Int. 4: 63-84.

Mishra, R. C. 1997. Perspectives in Indian Apiculture, p. 363. Agro Botanical Publishers, Bikaner, India.

Naik, D. G., A. H. Kapadi, M. K. Singh, M. C. Suryanarayana, and K. K. Kshirsagar. 1989. Lure development for Indian hive bees. Indian Bee J. 51: 47-50.

Naik, D. G., P. Banhatti, S. S. Chawda, and D. Thomas. 2002. 2-Heptanone as a repellent for Apis florea. J. Apic. Res. 40: 59-61.

Naik, D. G., P. Banhatti, S. S. Chawda, and D. Thomas. 2003. Fagara budrunga fruit extract as an attractant for Apis cerana. J. Apic. Res. 42: 48-49.

Naik, D. G., C. Dandge, H. Puntambekar, T. Patil. 2005. Attractant and repellent properties of Swertia densifolia leaf extract towards Apis cerana indica. J. Apic. Res. 44:116-118

Naik, D. G., C. Dandge, H. Puntambekar, and P. Deshpande. 2008. Chemical examination of Swertia densifolia leaf essential oil and its repellent activity towards Apis cerana indica F. J. Apic. Res. 47: 63-67.

Naik, D. G., C. Dandge, and P. Deshpande. 2010a. 'Pheromone-like' properties of de-oiled leaf extract of Swertia 
densifolia towards Apis cerana indica F. J. Apic. Res. 49: 149-153.

Naik, D. G., H. Puntambekar, and P. Anantpure. 2010b. Essential oil of Terminalia chebula fruits as a repellent for the Indian honeybee Apis florea. Chem. Biodivers. 7: 1303-1310.

Naik, D. G., C. N. Dandge, and S. V. Rupanar. 2011. Chemical examination and evaluation of antioxidant and antimicrobial activities of essential oil from Gymnema sylvestre $\mathrm{R}$. Br. leaves. J. Essent. Oil Res. 23: 12-19.

Naik, D. G., H. S. Vaidya, and T. P. Namjoshi. 2013. Essential oil of Indian propolis:chemical composition and repellency against the honeybee Apis florea. Chem. Biodivers. 10: 649-657.

Nerio, L. S., J. Olivero-Verbel, and E. Stashenko. 2010. Repellent activity of essential oils: a review. Bioresour. Technol. 101: 372-378.

Nicodemo, D., and R. H. Nogueiracouto. 2004. Use of repellents for honeybees (Apis mellifera L.) in vitro in the yellow passion-fruit (passiflora edulis deg) crop and in confined beef cattle feeders. J. Venom. Anim. Toxin. Trop. Dis. 10: 77-85.

Regnault-Roger, C., C. Vincent, and J. T. Arnason. 2012. Essential oils in insect control: low risk products in a highstakes world. Annu. Rev. Entomol. 57: 405-424.

Ridout, M. S., M. J. Faddy, and M. G. Soloman. 2006. Modelling the effects of repellent chemicals on foraging bees. Appl. Stat. 55: 63-75.

Sackin, B. M. and Y. Fishman. 1998. Honeybee repellent composition comprising tea tree oil. 14 April (1998). U. S. patent. 1209(2): 1355, II 14.

Sukumar, K., M. J. Perich, and L. R. Boobar. 1991. Botanical derivatives in mosquito control: a review. J. Am. Mosq. Control Assoc. 7: 210-237.

Woods D. F., S. Dimitratos, and R. Justice. 2014. Improved honeybee repellents and uses thereof. 12 March. Eur patent 270457882 .

Received 12 August 2014; accepted 10 October 2014. 